\title{
A Panel Granger Causality Test of Investment in ICT Capital and Economic Growth: Evidence From Developed and Developing Countries*
}

\begin{abstract}
Ayoub Yousefi
Western University, London, Canada

This paper applies the Pairwise Panel Granger Causality test to examine the relationship between ICT (information and communication technology) expenditure and the rate of growth of GDP (gross domestic product) per capita. This is accomplished by using cross-country time-series data for a total of 70 developed and developing countries for the period from 2003 to 2008 . The study reveals that the existence of causality and its direction differ across different income-group of countries and over the number of lags included. ICT investment expenditure as a percentage of GDP appears to cause the rate of growth of GDP per capita for the high income group and all income groups combined with lags higher than one year. However, for the upper- and lower-middle income groups, the study detects causality in neither direction. Also, when only one lag is included, the study suggests no causality in either direction for any of the income-groups of countries.
\end{abstract}

Keywords: investment in ICT (information and communication technology), the rate of growth of GDP (gross domestic product) per capita, causality, developed countries, developing countries

\section{Introduction}

Investment in ICT (information and communication technology) capital has shown in the past to have considerable impact on GDP (gross domestic product) growth. There are a large number of empirical studies devoted to identifying the sources of growth, such as gross fixed capital formation and investment in ICT capital. The study by Organisation for Economic Co-operation and Development [OECD] (2003) suggests that investment in ICT accounted for between 0.3 and 1.3 percentage points of growth in GDP in a selected group of countries over the period from 1995 to 2000. Moreover, such a contribution has been, with a few exceptions, higher in the period from 1995 to 2000 than from 1990 to 1995. Also, the study by Oliner and Sichel (2000) concludes that production and use of IT have contributed significantly to the acceleration in labor productivity growth in the US economy from 1991-1995 to 1996-1999.

For developing countries, the World Bank reported that firms that use ITC become efficient and more competitive. In particular, during the period from 2000 to 2003, sales growth, profitability, and total factor

\footnotetext{
* Project Support: This paper is supported by a Research Grant from King's University College at Western University, Canada. Ayoub Yousefi, associate professor of economics, Department of Economics, Business and Mathematics, King's University College at Western University, Canada.

Correspondence concerning this article should be addressed to Ayoub Yousefi, 266 Epworth Ave. London, Ontario N6A 2M3, Canada.E-mail: ayousefi@uwo.ca.
} 
productivity of enterprises that used ICT were higher than those that did not by $3.4,5.1$, and 1 percentage points, respectively. Although developing countries are markedly behind developed countries in investing in R\&D (research and development) and adapting ICTs, these countries had higher growth than developed countries during the last decade.

Despite a substantial literature that seeks to empirically document the growth and productivity impact of investment in ICT capital, the plausible feedback from economic growth to capital accumulation or investment in ICT capital has not been subjected to an adequate level of examination. As of today, there remain important questions to be answered: Does investment in ICT capital boost economic growth; does economic growth lead to more investment in ICT; or does causality run in both directions? Whatever the answers to these questions are, it has profound bearing for the larger objective of economic growth. The inevitable competition pressure brought about by globalization has pushed the "targeted rate of growth" to the top of the list of the major macroeconomic policy challenges, particularly for developing nations. As to how much ICT and non-ICT capital stocks are required to achieve, the targeted rate of growth depends, in a fundamental way, on the identification of the direction of causality and the estimated impact coefficients. The studies, which have made effort to answer these questions, embody sever limitations which will be reviewed below. The aim of this study is to remedy such shortfalls in the literature by investigating causality between investment in ICT and economic growth. New estimates are obtained, of causal relationship between the rate of growth of GDP per capita, as proxy for economic growth, and the share of expenditure in ICT capital by using such series for a group of 70 countries over the period from 2003 to 2008.

The remainder of the paper is organized as follows: Section 2 lists a brief review of theoretical foundation and empirical studies related to the ICT capital and economic growth; section 3 presents the methodological framework for the study of causality; section 4 provides the sources of data and explanation; section 5 summarizes the statistics and empirical results; and finally, section 6 presents the conclusion and policy implications of the paper.

\section{Literature Review}

There exist a growing body of researches aimed at documenting the impact of ICT capital on labor productivity and economic growth for both developed and developing countries. Researches involving developed countries, particularly the US economy, constitute the dominant part of the literature. For instance, OECD (2003), Ahmad, Schreyer, and Wölfl (2004), and Oliner and Sichel (2000) all examined the relationship for the OECD member countries. A small sample of studies at the cross country aggregate level are Jorgenson, Ho, and Stiroh (2002), Colecchia and Schreyer (2002), Van Ark, Melka, Mulder, Timmer, and Ypma (2002), Schreyer (2000), Daveri (2002), and Kottemann and Boyer-Wright (2009). Also at the aggregate level, there are studies, such as Dewan and Kraemer (2000) and Becchetti and Adriani (2005), which cover a large number of both developed and developing countries. From these studies, it is reasonable to conclude that the impact of ICT capital on economic growth and labor productivity has been positive and mostly statistically significant in developed economies. For developing countries, however, the results are mixed in terms of the impact and statistical significance.

According to OECD (2003), the share of investment in ICT capital in total GDP has been rising since 1980s. The shares, however, have been different among the OECD members with the highest standing at more than $4 \%$ for the United States and the lowest standing at roughly 2\% for France in 2001. For Canada, the United Kingdom, Sweden, Denmark, the Netherlands, Australia, and Japan, the figures were between healthy 
3\%-4\%. Also, according to OECD (2003), the contribution of investment in ICT capital to GDP growth has been higher in the 1995-2000 than the 1990-1995 period for all OECD members, except for Finland and Korea. The highest figure in the latter period was 1.3 percentage points for Australia and 1.2 percentage points for Korea, followed by 1.0 percentage point for the United States, 0.7 percentage point for Canada, and the lowest at 0.3 percentage point for France (Table 1).

Table 1

The Impact of ICT Investment on GDP Growth: Results From National Studies

\begin{tabular}{|c|c|c|c|c|c|c|c|}
\hline & \multicolumn{2}{|c|}{$\begin{array}{l}\text { GDP } \\
\text { growth }\end{array}$} & \multicolumn{2}{|c|}{$\begin{array}{l}\text { Labor Prod. } \\
\text { growth }\end{array}$} & \multicolumn{2}{|c|}{$\begin{array}{c}\text { Contribution } \\
\text { of ICT }\end{array}$} & \multirow[t]{2}{*}{ Notes } \\
\hline & 1990-1995 & $1995-2000$ & $1990-1995$ & $1995-2000$ & 1990-1995 & $1995-2000$ & \\
\hline \multicolumn{8}{|l|}{ United States } \\
\hline Oliner and Sichel (2000) & - & - & 1.5 & 2.3 & 0.5 & 1.0 & 1991-1995; 1996-2001 \\
\hline Jorgenson et al. (2002) & 2.5 & 4.0 & 1.4 & 2.7 & 0.5 & 1.0 & $1990-1995 ; 1995-1999$ \\
\hline Bureau of Labor Statistics & - & - & 1.5 & 2.7 & 0.4 & 0.9 & $1990-1995 ; 1995-2000$ \\
\hline \multicolumn{8}{|l|}{ Japan } \\
\hline Miyagawa and Harada (2002) & - & - & 2.2 & 1.4 & 0.1 & 0.4 & $1990-1995 ; 1995-1998$ \\
\hline Motohashi (2001) & 1.7 & 1.5 & - & - & 0.2 & 0.5 & $1990-1995 ; 1995-2000$ \\
\hline \multicolumn{8}{|l|}{ Germany } \\
\hline $\begin{array}{l}\text { Gordon and Rhine-Westphalia } \\
\text { Institute of Economic } \\
\text { Research (2002) } \\
\end{array}$ & 2.2 & 2.5 & 2.6 & 2.1 & 0.4 & 0.5 & $1990-1995 ; 1995-2000$ \\
\hline \multicolumn{8}{|l|}{ France } \\
\hline $\begin{array}{l}\text { Cette, Mairesse, and Kocoglu } \\
(2002)\end{array}$ & 0.5 & 2.2 & 1.6 & 1.1 & 0.2 & 0.3 & $1990-1995 ; 1995-2000$ \\
\hline \multicolumn{8}{|l|}{ United Kingdom } \\
\hline Oulton (2001) & 1.4 & 3.1 & 3.0 & 1.5 & 0.4 & 0.6 & 1989-1994; 1994-1998 \\
\hline \multicolumn{8}{|l|}{ Canada } \\
\hline $\begin{array}{l}\text { Armstrong, Harchaoui, } \\
\text { Jackson, and Tarkhani (2002) }\end{array}$ & 1.5 & 4.9 & - & - & 0.4 & 0.7 & $1988-1995 ; 1995-2000$ \\
\hline Khan and Santos (2002) & 1.9 & 4.8 & - & - & 0.3 & 0.5 & $1991-1995 ; 1996-2000$ \\
\hline \multicolumn{8}{|l|}{ Australia } \\
\hline $\begin{array}{l}\text { Parham, Roberts, and Sun } \\
\text { (2001) }\end{array}$ & - & - & 2.1 & 3.7 & 0.7 & 1.3 & $\begin{array}{l}1989 / 1990-1994 / 1995 ; \\
\text { 1994/1995-1999/2000 }\end{array}$ \\
\hline Simon and Wardrop (2001) & 1.8 & 4.9 & 2.2 & 4.2 & 0.9 & 1.3 & $1991-1995 ; 1996-2000$ \\
\hline $\begin{array}{l}\text { Gretton, Gali, and Parham } \\
(2002)\end{array}$ & - & - & 2.2 & 3.5 & 0.6 & 1.1 & $\begin{array}{l}\text { 1989/1990-1994/1995; } \\
\text { 1994/1995-1999/2000 }\end{array}$ \\
\hline \multicolumn{8}{|l|}{ Belgium } \\
\hline $\begin{array}{l}\text { Kegels, Van Overbeke, and } \\
\text { Van Zandweghe (2002) }\end{array}$ & 1.5 & 2.8 & 1.9 & 1.9 & 0.3 & 0.5 & $1991-1995 ; 1995-2000$ \\
\hline \multicolumn{8}{|l|}{ Finland } \\
\hline Jalava and Pohjola (2002) & - & - & 3.9 & 3.5 & 0.6 & 0.5 & 1990-1995; 1996-1999 \\
\hline \multicolumn{8}{|l|}{ Korea } \\
\hline Kim (2002) & 7.5 & 5.0 & - & - & 1.4 & 1.2 & $1991-1995 ; 1996-2000$ \\
\hline \multicolumn{8}{|l|}{ Netherlands } \\
\hline Van Der Wiel (2002) & - & - & 1.3 & 1.5 & 0.4 & 0.6 & $1991-1995 ; 1996-2000$ \\
\hline
\end{tabular}

Source: OECD (2003). 
Colecchia and Schreyer (2002) compared the ICT contribution to GDP growth in nine OECD countries over the period from 1980 to 2000 . The study reveals that the ICT contributed between 0.2 and 0.5 percentage point per year to GDP growth. However, during the second half of the 1990s, the contribution rose to 0.3-0.9 percentage point per year. In a sum, the ICT-growth literature appears to produce strong empirical evidence that investment in ICT contributed significantly to GDP growth in developed economies, more so during the second half of the 1990s. Kottemann and Boyer-Wright (2009) empirically examined the associations of education quality, on-the-job training, the maturity of ICT use by individuals, businesses, and governments, and GDP per capita. By dividing the data of 122 developed and developing countries into high and low GDP groups, the study concludes that: (a) Both education quality and on-the-job training are important for GDP growth through ICT use by individuals, businesses, and governments, and (b) the direct association of education quality and on-the-job training with GDP per capita reveals high path coefficient significance level for low GDP group ( $R^{2}$ $=0.66)$ and low path coefficient significance level for high GDP group of countries $\left(R^{2}=0.58\right)$. In addition, Papaioannou and Dimelis (2007) used a sample of 42 developed and developing countries over the period from 1993 to 2001 to re-examine the relationship between ITC investment and labor productivity. The study suggests that while ICT capital and non-ICT capital have a statistically positive impact on productivity growth and the former is stronger than the latter. Also, the impact of ICT capital in developed countries is stronger than that of the developing countries.

Turning the attention to developing countries, there is some anecdotal evidence that these countries have shown the possibility of leapfrogging several stages of technological development which have resulted from substantial R\&D investments by developed economies over time. Panagariya (2000) argued that developing countries are much deeper inside the current technological nexus and, therefore, have larger potential benefits from moving into it. Such an argument has led some to believe that the gap between poor and rich countries might shrink at an even faster pace than before as developing countries gain access to these technologies. On the contrary, Ferran and Salim (2006) argued that such convergence tendencies are far from happening, as deficiencies in business practices caused by inadequate industrial and transportation infrastructures as well as organizational impediments overwhelm the benefits gained from importing physical ICT capital. Baliamoune-Lutz (2003) analyzed the determinants and effects of ICT diffusion in 46 developing countries for the period from 1998 to 2000 . The study shows that income and government trade policies affect ICT diffusion and among many ICT indicators only personal computers and the Internet host have a positive impact on income. More important, the study concludes that ICT diffusion can provide an additional source of economic growth, foster economic development, and enhance civil liberties and political rights. Furthermore, Ngwenyama and Morawczynski (2009) investigated factors affecting the efficiency of expansion of ICT in five emerging economies in Latin America: Argentina, Brazil, Chile, Colombia, and Peru, for the period from 1994 to 2001. The study concludes that efficient expansion of ICT requires not only deregulation of business environment, but also favorable economic and human conditions and enabling civil infrastructure.

The literature seems to suggest that the overall impact of ICT capital on economic growth in developing countries depends on a set of preconditions which are internal and external to their economies. Moreover, the so-called "enabling conditions" can vary considerably from one country to another depending on the stage of economic development. In sum, the debate over the impact of ICT capital on economic growth is far from over, as such impact varies across nations and over time. 
There is also another dimension to the above debate; the feedback from economic growth to capital accumulation and investment in ICT seems equally plausible. Such a feedback implies two important consequences: First, it renders the coefficient estimates of the single-equation capital accumulation-growth model biased and inconsistent; second, any policy implications derived from such models will be ill-founded, if not flawed. As a result, examination of the causality between investment in ICT capital and economic growth emerges as a necessary and promising research undertaking.

Podrecca and Carmeci (2001) examined causality between fixed investment shares and economic growth for the post-war period and suggested that contrary to the previous results in the literature, causality between the two variables runs in both directions. The empirical results are consistent with the predictions of Solow-type growth model, but they contrast with the classical view that fixed capital investment is the key to the long-run economic growth (Solow, 1956; 1957). ${ }^{1}$

Ghali and Al-Mutawa (1999) investigated the causal relationship between the share of fixed investment in GDP and the rate of growth of real GDP per capita for the group of seven major industrialized countries on an individual basis for the period from 1960 to 1995 . By using a time series VAR model, the results suggest that the causal relationship among the variables varies significantly across these countries. That is, causality among these variables seems to have country-specific nature which may run in either direction. In addition, Beil, Ford, and Jackson (2005) studied the causal relationship between the real investment by telecommunications firms and real GDP in the United States for the period from 1947 to 1997 . By using a 50-year time series and applying Granger-Sims causality test, the study concludes that investment by telecommunications firms is caused by (but does not cause) growth in GDP. Such strong suggestions appear somewhat doubtful as to how investments by these firms have resulted in no contribution to GDP growth during such a long period of time. Wolde-Rufael (2007) challenged the findings of this paper by re-testing the relationship by using the same data set and applying another version of Granger causality test pioneered by Toda and Yamamoto (1995). This study suggests a bi-directional causality (feedback) between the two variables.

From the above studies, which investigate the relationship between aggregate or industry-level investments and growth, none have focused specifically on the role of investment in ICT capital. To fill in this gap in the literature, this paper tests the causal relationship between the rate of growth of GDP per capita, as proxy for economic growth, and the share of ICT capital expenditure by using a series of a group of 70 countries for the period from 2003 to 2008 .

\section{Methodology}

The majority of common causality tests are based on Granger (1969). However, in a more fundamental way, Granger causality is not necessarily equivalent to the concept of "causation". It is rather close to the concept of "precedence". In the jargon of econometrics, a stationary time series $Y_{t}$ is said to fail to Granger-cause, another stationary time series $X_{t}$, if the inclusion of past values of $Y_{t}$ (added information of $Y_{\mathrm{t}}$

\footnotetext{
1 The feedback from economic growth to capital accumulation can be positioned within the context of exogenous vs. endogenous growth literature. According to standard neoclassical growth theory, once the economy reaches its steady state situation, investment in capital can no longer increase growth. This is indeed a manifestation of the so-called "exogenous growth" theory in which technological progress cannot be explained within the model. Despite its early popularity, the exogenous growth theory confronted widespread criticisms and eventually gave way to the "endogenous growth" model which allows growth to depend on capital accumulation even in the long run. The need for a well defined endogenous growth model is increasingly inevitable.
} 
variable) does not significantly reduce the predictive error variance of $X_{t}$. That is, for all $i>0$, the mean squared error (MSE) of a forecast of $X_{t+i}$ based on the information set of $\left(X_{t}, X_{t-1}, \ldots\right)$ is the same as the one which uses both $\left(X_{t}, X_{t-1}, \ldots\right)$ and $\left(Y_{t}, Y_{t-1}, \ldots\right)$. When only a linear function is concerned, $Y_{t}$ fails to Granger-cause $X_{t}$, if (Hamilton, 1994):

$$
\operatorname{MSE}\left[E\left(X_{t+1} \mid X_{t}, X_{t-1}, \ldots\right)\right]=\operatorname{MSE}\left[E\left(X_{t+1} \mid X_{t}, X_{t-1}, \ldots, Y_{t}, Y_{t-1}, \ldots\right)\right]
$$

A bivariate vector autoregressive (VAR) model with MA $(p)$ describing $X$ and $Y, Y_{t}$ does not Granger-cause $X_{t}$, if the coefficient matrices $\theta_{i}$ are lower triangular for all $i$ :

$$
\left[\begin{array}{l}
X_{t} \\
Y_{t}
\end{array}\right]=\left[\begin{array}{l}
C_{1} \\
C_{2}
\end{array}\right]+\sum_{i=1}^{p}\left[\begin{array}{ll}
\theta_{11, i} & \theta_{12, i} \\
\theta_{21, i} & \theta_{22, i}
\end{array}\right]+\left[\begin{array}{l}
X_{t-1} \\
Y_{t-1}
\end{array}\right]+\left[\begin{array}{l}
\varepsilon_{1 t} \\
\varepsilon_{2 t}
\end{array}\right]
$$

where $\left[C_{1}, C_{2}\right]$ is a vector of constants and $\varepsilon_{1 t}$ and $\varepsilon_{2 t}$ are uncorrelated random disturbances with zero mean and constant variances.

Granger (1988) suggested two different causalities in the VEC framework: (1) Short-run causality occurs from the lagged differences which capture the short-run dynamics of the system; (2) long-run causality carries its effect through the one period lagged error correction term, as the cointegration equation corrects the deviations from the long-run equilibrium. That is, in an error correction model, the cointegration relationship between the dependent and independent variables is usually interpreted as the long-run equilibrium relationship between the variables. According to Engle and Granger (1987), two variables are cointegrated, if they share the common stochastic trend. More generally, two variables are said to be cointegrated, if those two variables are not stationary in themselves but stationary in their first differences and if the linear combinations of those two variables are stationary, $I(0)$. Suppose there are $Y_{t} \sim I(1)$ and $X_{t} \sim I(1)$, then $Y_{t}$ and $X_{t}$ are cointegrated, if $Y_{t}-\beta Y_{t}$ is $I(0)$. If a cointegration between $Y_{t}$ and $X_{t}$ is established, then it implies that there is a long-run relationship between the two variables.

A vector error correction model (VECM) is a restricted VAR model for cointegrated non-stationary variables which includes one-period lagged error terms. Also, all the variables except the error correction terms are expressed in differenced forms, since VECM deals with non-stationary variables. An example of VEC relationship can be expressed as follows:

$$
\begin{aligned}
\Delta L X_{t} & =\alpha_{1}+\gamma_{1} \theta_{t-1}+\sum_{i=1}^{r} \alpha_{1 i} \Delta L X_{t-i}+\sum_{i=1}^{s} \beta_{1 i} \Delta L Y_{t-i}+\varepsilon_{1 t} \\
\Delta L Y_{t} & =\beta_{1}+\gamma_{2} \theta_{t-1}+\sum_{i=1}^{r} \alpha_{2 i} \Delta L X_{t-i}+\sum_{i=1}^{s} \beta_{2 i} \Delta L Y_{t-i}+\varepsilon_{2 t}
\end{aligned}
$$

where $X_{t}$ and $Y_{t}$ are the two endogenous variables.

Each equation includes corresponding number of $E C$ and a random error term $\varepsilon_{t}$. The $E C$ reflects the response to the deviation from the long-run equilibrium, since $E C$ is zero in the long-run equilibrium. The coefficients of the error correction terms $\gamma_{1}$ and $\gamma_{2}$ are also referred to as the speed-of-adjustment parameters. The null hypothesis of short-run non-causality from $Y$ to $X$ is identified by the significance of $\beta_{1 i}$ and the null hypothesis of the long-run causality is verified from the significance of $\gamma_{1}$ and $\gamma_{2}$, the coefficients of error correction terms.

The VAR and VEC models described above and in particular Granger-causality test are developed originally to deal with time series data. The present study however uses panel data. Because the Granger causality test assumes stationary time series, this paper tests all the time series for the presence of unit roots. This paper applies the panel unit root procedure which increases the number of observations used for the test. 
This has shown to result in higher testing power than the unit root tests based on individual time series. Thus, for a given level of significance, it is more likely to identify a false null hypothesis. When these tests fail to suggest unit roots, this paper then applies the panel estimation of a time-stationary VAR model as follows:

$$
Y_{i t}=\alpha_{0}+\sum_{\mathrm{l}=0}^{m} \alpha_{1} X_{i t-1}+\sum_{i=1}^{n} \gamma_{1} Y_{i t-1}+\mu_{i}+v_{i t}
$$

where $Y_{i t}$ is annual rate of growth of GDP per capita for country $i(i=1,2,3, \ldots, N)$ and $(t=1,2,3, \ldots, T) ; X_{i t}$ is investment in ICT capital, as a percentage of GDP for country $i$; $\mu_{i}$ is country specific effect; $v_{i t}$ is disturbance term assumed to be independently distributed across countries with a zero mean and constant variance; $m$ and $n$ are numbers of lagged $X_{t}$ and $Y_{t}$ variables.

It is common in the Granger causality studies to test whether causation runs in both directions. To this end, this paper also tests the following equation:

$$
X_{i t}=\beta_{0}+\sum_{l=0}^{k} \beta_{1} Y_{i t-1}+\sum_{i=1}^{l} \delta_{1} X_{i t-1}+\varepsilon_{i}+\epsilon_{i t}
$$

where $\varepsilon_{i}$ is country specific effect; $\epsilon_{i t}$ is the disturbance terms assumed to be independently distributed across countries with a zero mean and constant variance; $k$ and $l$ are the numbers of lagged $Y_{t}$ and $X_{t}$ variables.

This paper runs bivariate regressions of (3) and (4) for all possible pairs of ICT investment and the rate of growth of GDP per capita series for each income group, as well as the all income groups of countries combined. It reports the $F$-statistics which are the $x^{2}$ Wald statistics for the joint significance of each of the other lagged endogenous variables in the equation. That is the following for equations (3) and (4), respectively:

$$
\begin{aligned}
& \gamma_{1}=\gamma_{2}=\ldots=\gamma_{n}=0 \\
& \delta_{1}=\delta_{2}=\ldots=\delta_{l}=0
\end{aligned}
$$

Since the theory of causality depends substantially on all past information, given the annual series, this paper starts with a feasible maximum of four lags and reduces it sequentially to one year.

\section{Explanation and Sources of Data}

To examine whether the income level of the group of countries, as a proxy for the stage of development, has any bearing on the existence or direction of causality, this paper adopts the World Bank income group classification: high income, upper-middle income, lower-middle income, and low income groups. Unfortunately, it was unable to collect enough observations for the low-income group for a meaningful examination. The benchmark income levels as well as the list of the countries in each group are tabulated in Appendix 1.

The most recent set of indicators of ICT development for 144 countries has been launched by the World Bank. The set represents economic and social context, ICT sector structure, and ICT sector performance. The latter category accounts for access, quality, affordability, institutional efficiency and sustainability, and ICT applications. The ICT applications sub-section includes: ICT expenditure as a percentage of GDP; E-government readiness index (scale 0-1); secure Internet services (per one million people); and the percent of schools connected to the Internet. For the World Bank definitions of ICT, it can be seen from Appendix 2.

From the ICT applications, this paper obtains the ICT expenditure (\% GDP) as a measure of expenditure on aggregate ICT capital for a total of 70 countries selected based on availability of all other needed data sets 
for the period from 2003 to $2008 .^{2}$ According to Global Insight, ICT expenditure includes: hardware (computers, storage devices, printers, and other peripherals), software (operating systems, programming tools, utilities, applications, and internal software development), services (information technology consulting, computer and network systems integration, Web hosting, data processing services, and other services), communications services (voice and data communications services), and wired and wireless communications equipment. ${ }^{3}$ Atrostic and Nguyen (2002) suggested a positive significant relationship between computer networks (both EDI and the Internet) and labor productivity for the United States. Computer networks were estimated to increase labor productivity by almost $5 \%$. Similar conclusions have also been documented for Japan and Germany (OECD, 2003). The mean of the ICT expenditure for the high income group remained fairly around $6.29 \%$ over the period from 2003 to 2008 . It rose from $6.26 \%$ in 2003 to $6.46 \%$ in 2006 and declined steadily to $6.02 \%$ in 2008 (see Figure 1). On one hand, the countries with high average ICT expenditures were Czech Republic (8.16\%), Hungary (10.02\%), South Korea (9.22\%), and Singapore (8.78\%). On the other hand, Greece (4.59\%), Ireland (4.75\%), Norway (4.06\%), and Slovenia (4.35\%) were among the low average ICT expenditure countries. Over the same period, the means of the ICT expenditure for the upper-middle income and the lower-middle income groups were $5.33 \%$ and $5.75 \%$, respectively. Among the lower-middle income group, Indonesia (3.26\%), Nigeria (3.64\%), Pakistan (3.88\%), and Sri Lanka (3.52\%) had the lowest mean ICT expenditure figures. Unlike the high income and upper-middle income groups for which the means of ICT expenditure declined steadily since 2006, the ICT expenditure kept rising for the lower-middle income group over the period. When the all income groups combined, the inverted U-shaped mean ICT expenditure with the turning point at 2006 can still be observed (see Figures 1-4, Retrieved from http://data.worldbank.org/data-catalog/world-development-indicators).

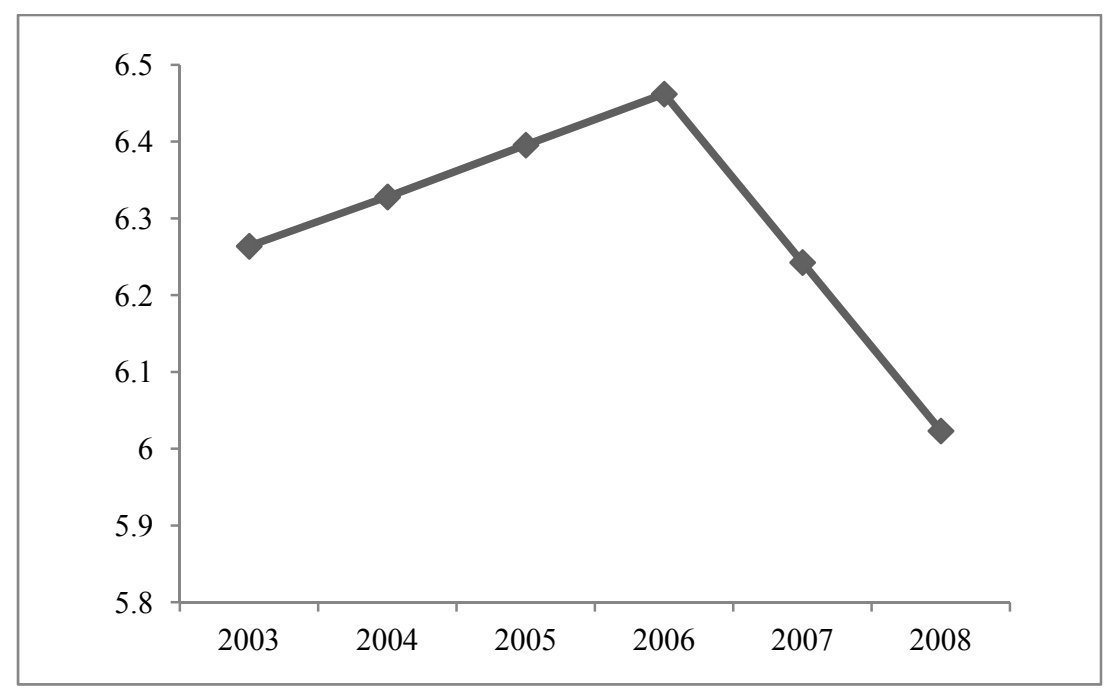

Figure 1. ICT expenditure as a percent of GDP (high income group).

\footnotetext{
${ }^{2}$ World Bank discontinues publishing ICT expenditure and the variable has been dropped from the World Development Indicators (WDI) database all together. As such, 2008 remains the latest year for which data set for the subject of this paper is available.

${ }^{3}$ Some forms of ICT capital appear to be more important in enhancing firms' performance than other forms of capital. Specifically, computer networks that allow to better integrate activities throughout the value chain lead to the so-called "spillover effect" and higher overall productivity.
} 


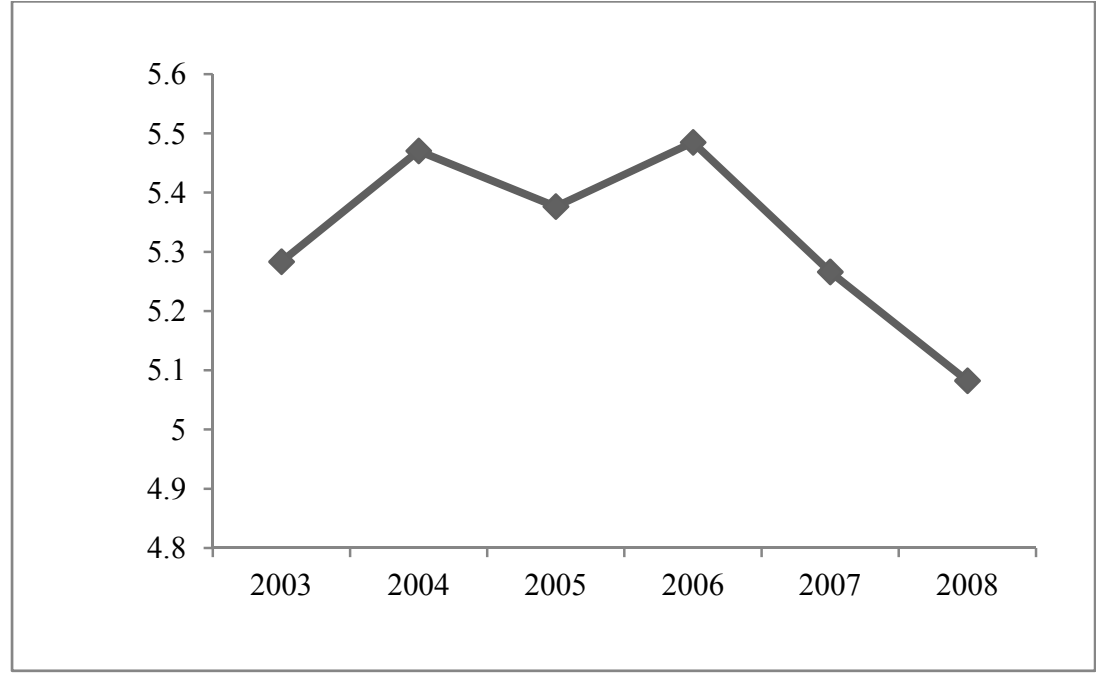

Figure 2. ICT expenditure as a percent of GDP (upper-middle income group).

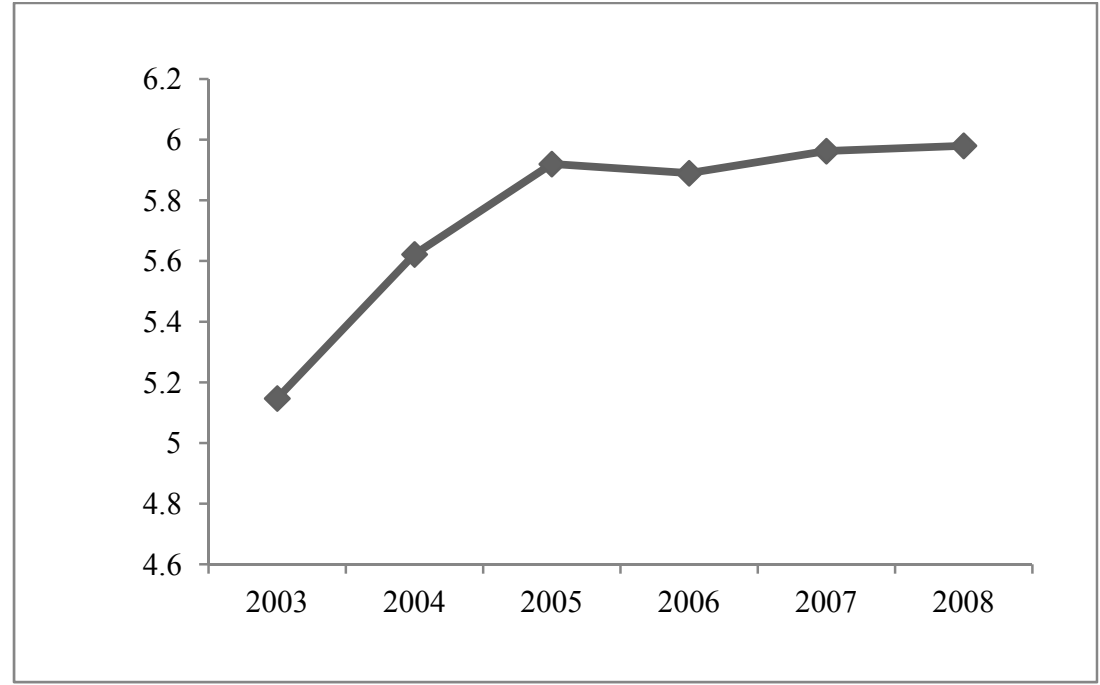

Figure 3. ICT expenditure as a percent of GDP (lower-middle income group).

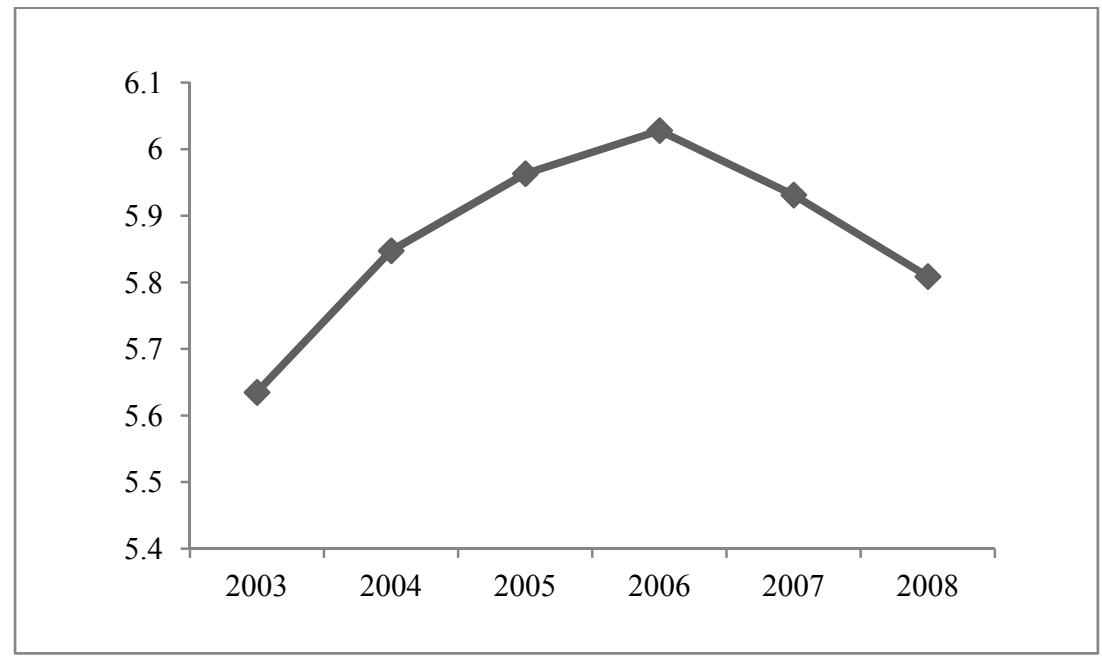

Figure 4. ICT expenditure as a percent of GDP (all income group). 
This paper collected the rate of growth of GDP per capita figures (Retrieved from http://data.worldbank.org/data-catalog/world-development-indicators) for the same group of countries and the same period of time as following (Figures 5-8). From these figures, some observations should be highlighted. Firstly, the average rate of growth of GDP for the all groups of countries combined stands at $3.56 \%$ over the period with $2.43 \%, 4.45 \%$, and $4.53 \%$ for the high income, upper-middle income, and lower-middle income groups, respectively. This observation suggests that the lower the level of income level is, and the higher the rate of growth will be. From the lower-middle income group, China stands out with an impressive average rate of growth of $10.06 \%$ over the period. Secondly, starting in 2006, the average rate of growth GDP has fallen for the all income groups, but somewhat slowly for the lower-middle income group. While the figure has fallen from $4.20 \%$ in 2006 to $2.22 \%$ in 2008 for the all income groups combined, it has fallen sharply from $3.28 \%$ to $0.56 \%$ for the high income group during the same period. By visual comparison of the means of ICT expenditure and GDP growth, it seems that these figures vary non-uniformly across different income groups over the period from 2003 to 2008. The empirical examination below aims at capturing statistical properties of these series.

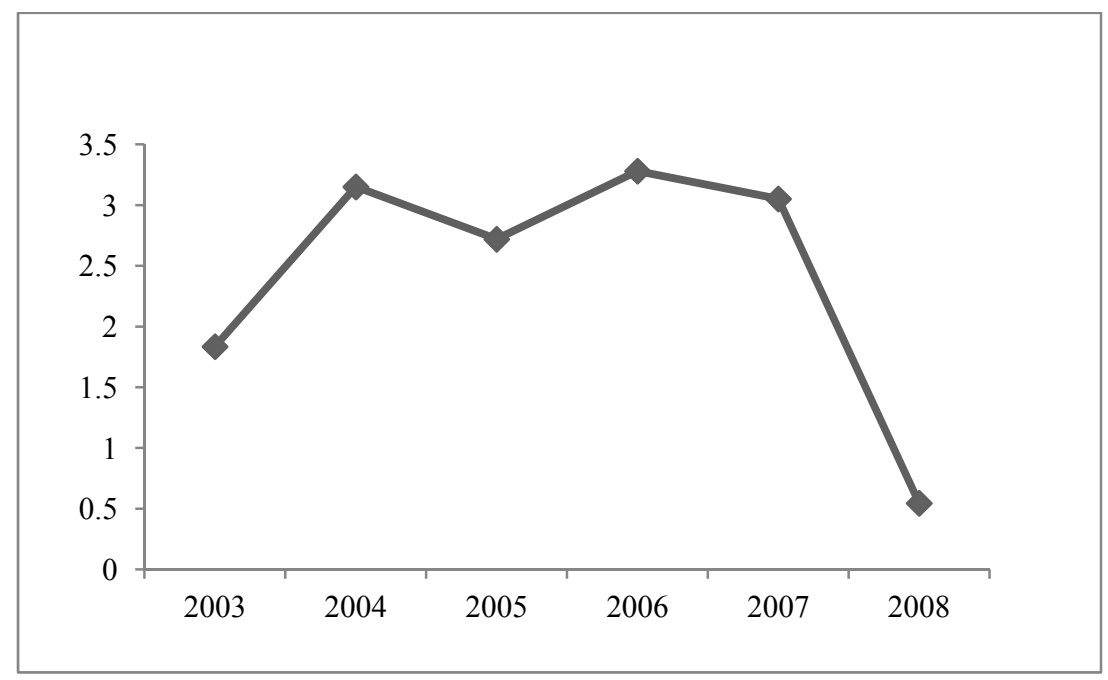

Figure 5. Per capita rate of growth of GDP (\%) (high income group).

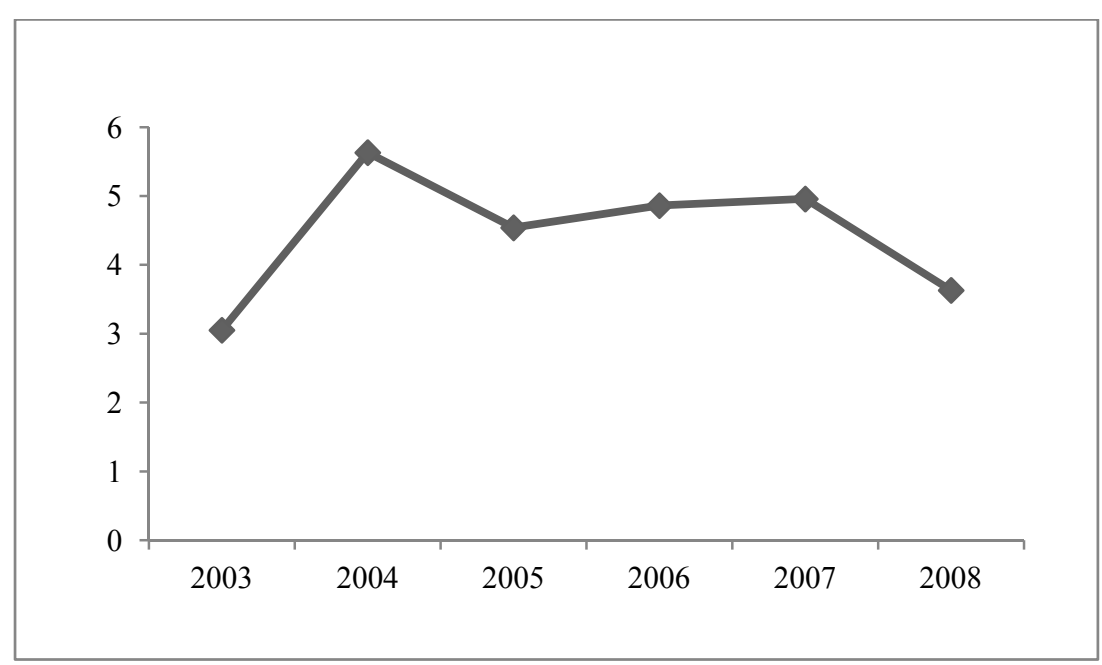

Figure 6. Per capita rate of growth of GDP (\%) (upper-middle income group). 


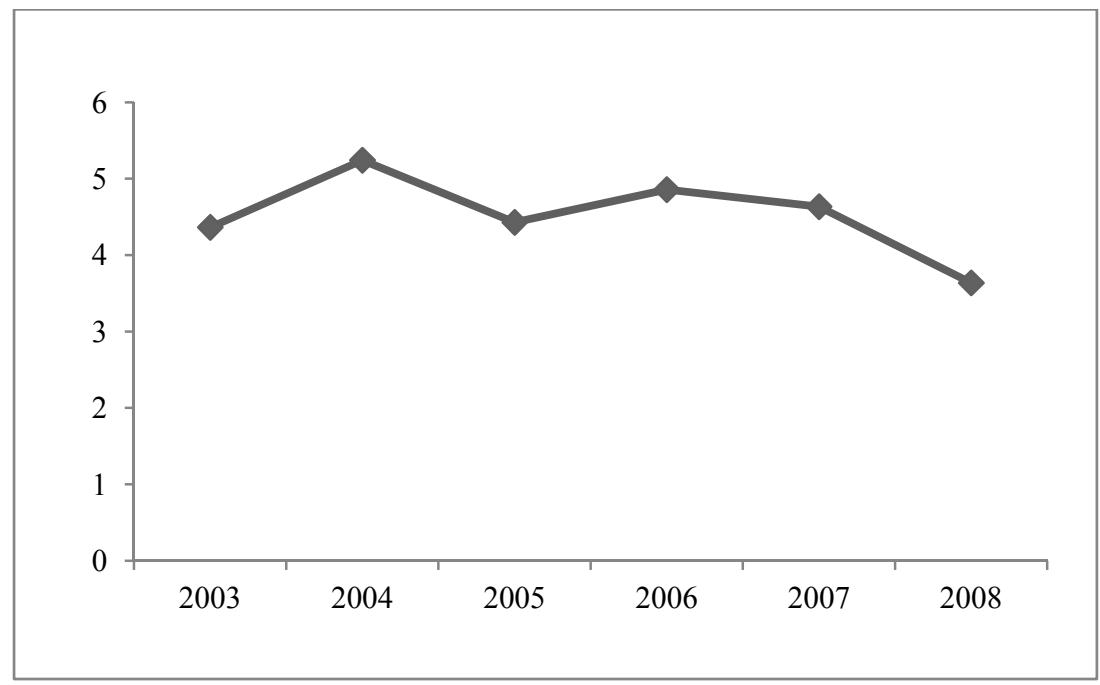

Figure 7. Per capita rate of growth of GDP (\%) (lower-middle income group).

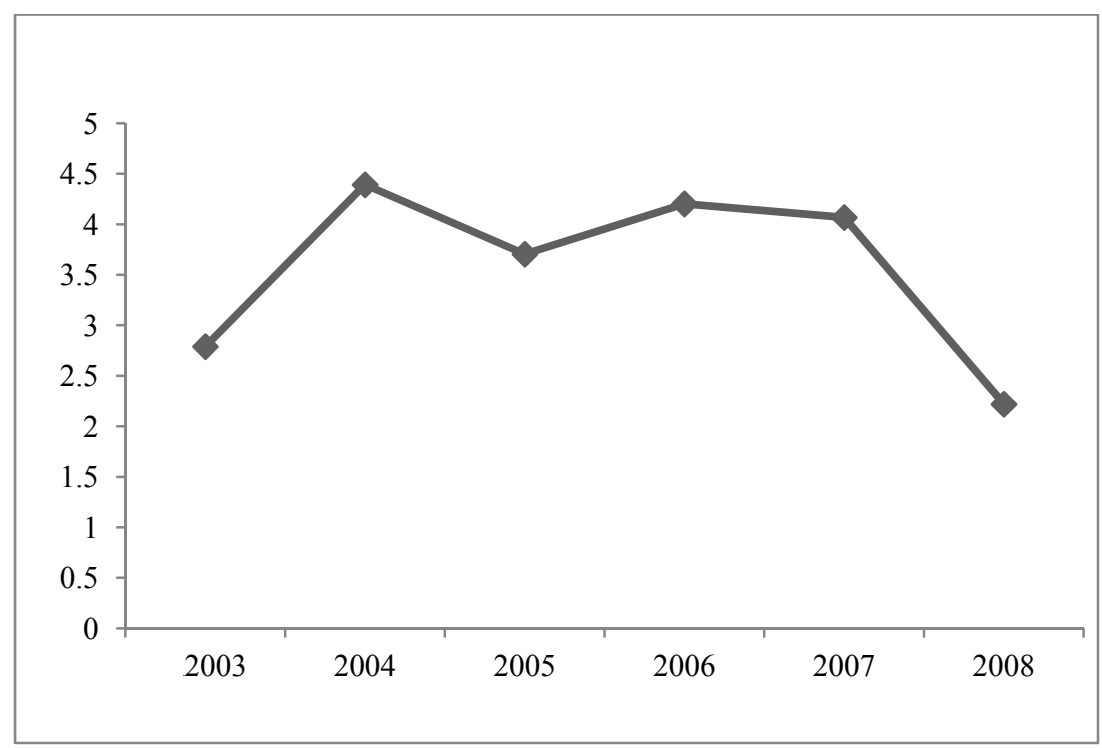

Figure 8. Per capita rate of growth of GDP (\%) (all income group).

\section{Empirical Results}

To implement the Granger causality test, all time series should be tested for the presence of unit roots. This paper applies the panel unit root procedure which increases the number of observations used for the test which is shown to have higher testing power than the unit root tests based on individual time series. This is because, for a given level of significance, it is more likely to identify a false null hypothesis. To do so, this paper carries out a battery of panel unit root tests on the level of series of the variables: first, a common unit root test (Levin, Lin, and Chut $t^{*}$ ) which assumes a common unit root process across sections (Levin, Lin, \& Chu, 2002); second, individual unit root tests (Im, Pesaran, Shin W-Stat., the ADF-Fisher Chi-square, and PP-Fisher Chi-square) which allow for individual unit root process varying across sections (Im, Pesaran, \& Shin, 2003; Dickey \& Fuller, 1979; Phillips \& Perron, 1988). These tests resemble combining individual unit root tests to obtain a panel unit root process. The summary statistics are reported in Tables 2 and 3. 
Based on the test statistics, this paper rejects the null hypothesis of the presence of a common unit root as well as individual unit root processes in the rate of growth of GDP per capita series for the three subgroups as well as the all income groups combined at the $1 \%$ level of significance, except for Im, Pesaran, and Shin W-Stat. test for the high income group. That is, statistics suggest that the rate of growth of GDP per capita holds stationary series properties. Also, for the ICT expenditure series, it rejects the presence of a unit root for the three subgroups as well as the all income groups combined when assuming a common unit root process at the $1 \%$ level of significance. When assuming individual unit root process, however, the test statistics are mixed, making it difficult to conclude either way. In sum, the statistics suggest stationary processes for the two series for all tests with the assumption of a common unit root process and in most cases with the assumption of individual unit root processes.

To examine the robustness of the results, it carries out tests to verify the existence or absence of cointegration process by the two series. It implements Pedroni Residual Cointegration test among the said variables for the income groups and all the income groups combined (Pesaran \& Shin, 1995; Pesaran, Shin, \& Smith, 2000). For the individual income groups, the statistics are mixed and are not reported here, making it difficult to reject (or not to reject) the null hypothesis of no cointegration at any level of statistical significance. However, for the all income groups combined, it fails to reject the null hypothesis of no cointegration. As a result, the pre-testing all together validates the implementation of the panel VAR regression of the rate of growth of GDP per capita and the ICT expenditure series.

Table 2

Panel Unit Root Test, ICT Expenditure (\% GDP)

\begin{tabular}{|c|c|c|c|c|}
\hline High income group & Statistic & Prob. $^{* *}$ & Sections & Obs. \\
\hline \multicolumn{5}{|c|}{ Null: Unit root (assumes a common unit root process) } \\
\hline Levin, Lin, and Chut $t^{*}$ & -2.256 & 0.012 & 31 & 155 \\
\hline \multicolumn{5}{|c|}{ Null: Unit root (assumes individual unit root process) } \\
\hline Im, Pesaran, and Shin W-Stat. & 1.974 & 0.976 & 31 & 155 \\
\hline ADF-Fisher Chi-square & 38.690 & 0.991 & 31 & 155 \\
\hline PP-Fisher Chi-square & 48.891 & 0.887 & 31 & 155 \\
\hline Upper-middle income group & Statistic & Prob. $^{* *}$ & Sections & Obs. \\
\hline \multicolumn{5}{|c|}{ Null: Unit root (assumes a common unit root process) } \\
\hline Levin, Lin, and Chut $t^{*}$ & -7.913 & 0.000 & 18 & 90 \\
\hline \multicolumn{5}{|c|}{ Null: Unit root (assumes individual unit root process) } \\
\hline Im, Pesaran, and Shin W-Stat. & -1.176 & 0.120 & 18 & 90 \\
\hline ADF-Fisher Chi-square & 54.681 & 0.024 & 18 & 90 \\
\hline PP-Fisher Chi-square & 78.618 & 0.000 & 18 & 90 \\
\hline Lower-middle income group & Statistic & Prob. $^{* *}$ & Sections & Obs. \\
\hline \multicolumn{5}{|c|}{ Null: Unit root (assumes a common unit root process) } \\
\hline Levin, Lin, and Chut $t^{*}$ & -3.587 & 0.000 & 19 & 95 \\
\hline \multicolumn{5}{|c|}{ Null: Unit root (assumes individual unit root process) } \\
\hline Im, Pesaran, and Shin W-Stat. & 0.671 & 0.749 & 19 & 95 \\
\hline ADF-Fisher Chi-square & 43.317 & 0.255 & 19 & 95 \\
\hline PP-Fisher Chi-square & 71.010 & 0.000 & 19 & 95 \\
\hline
\end{tabular}




\begin{tabular}{lllll}
\hline All income group & Statistic & Prob. $^{* *}$ & Sections & Obs. \\
\hline Null: Unit root (assumes a common unit root process) & & & & \\
\hline Levin, Lin, and Chut $t^{*}$ & -6.429 & 0.0000 & 70 & 350 \\
\hline Null: Unit root (assumes individual unit root process) & & & & 350 \\
\hline Im, Pesaran, and Shin W-Stat. & 1.506 & 0.934 & 70 & 350 \\
ADF-Fisher Chi-square & 133.730 & 0.633 & 70 & 350 \\
PP-Fisher Chi-square & 198.685 & 0.000 & 70 & \\
\hline
\end{tabular}

Notes. ** Probabilities for Fisher tests are computed using an asymptotic Chi-square distribution; all other tests assume asymptotic normality; sample is from 2003 to 2008; exogenous variables are individual effects, automatic selection of maximum lags, automatic lag length selection based on SIC: 0, Newly-West automatic bandwidth selection using Bartlett kernel, and balanced observations for each test.

Table 3

Panel Unit Root Test, Rate of Growth of GDP Per Capita (\%)

\begin{tabular}{|c|c|c|c|c|}
\hline High income group: & Statistic & Prob. $^{* *}$ & Sections & Obs. \\
\hline \multicolumn{5}{|c|}{ Null: Unit root (assumes a common unit root process) } \\
\hline Levin, Lin, and Chut $t^{*}$ & -7.479 & 0.000 & 31 & 155 \\
\hline \multicolumn{5}{|c|}{ Null: Unit root (assumes individual unit root process) } \\
\hline Im, Pesaran, and Shin W-Stat. & -0.895 & 0.186 & 31 & 155 \\
\hline ADF-Fisher Chi-square & 77.601 & 0.087 & 31 & 155 \\
\hline PP-Fisher Chi-square & 102.686 & 0.001 & 31 & 155 \\
\hline Upper-middle income group & Statistic & Prob. $^{* *}$ & Sections & Obs. \\
\hline \multicolumn{5}{|c|}{ Null: Unit root (assumes a common unit root process) } \\
\hline Levin, Lin, and Chut $t^{*}$ & -6.017 & 0.000 & 18 & 64 \\
\hline \multicolumn{5}{|c|}{ Null: Unit root (assumes individual unit root process) } \\
\hline Im, Pesaran, and Shin W-Stat. & -2.341 & 0.010 & 18 & 64 \\
\hline ADF-Fisher Chi-square & 64.807 & 0.002 & 18 & 64 \\
\hline PP-Fisher Chi-square & 76.872 & 0.000 & 18 & 64 \\
\hline Lower-middle income group & Statistic & Prob. $^{* *}$ & Sections & Obs. \\
\hline \multicolumn{5}{|c|}{ Null: Unit root (assumes a common unit root process) } \\
\hline Levin, Lin, and Chut $t^{*}$ & -8.446 & 0.000 & 19 & 95 \\
\hline \multicolumn{5}{|c|}{ Null: Unit root (assumes individual unit root process) } \\
\hline Im, Pesaran, and Shin W-Stat. & -1.413 & 0.079 & 19 & 95 \\
\hline ADF-Fisher Chi-square & 52.761 & 0.056 & 19 & 95 \\
\hline PP-Fisher Chi-square & 66.008 & 0.003 & 19 & 95 \\
\hline All income group & Statistic & Prob. $^{* *}$ & Sections & Obs. \\
\hline \multicolumn{5}{|c|}{ Null: Unit root (assumes a common unit root process) } \\
\hline Levin, Lin, and Chut $t^{*}$ & -12.541 & 0.000 & 70 & 350 \\
\hline \multicolumn{5}{|c|}{ Null: Unit root (assumes individual unit root process) } \\
\hline Im, Pesaran, and Shin W-Stat. & -2.689 & 0.004 & 70 & 350 \\
\hline ADF-Fisher Chi-square & 203.249 & 0.000 & 70 & 350 \\
\hline PP-Fisher Chi-square & 256.787 & 0.000 & 70 & 350 \\
\hline
\end{tabular}

Notes. ${ }^{* *}$ Probabilities for Fisher tests are computed using an asymptotic Chi-square distribution; all other tests assume asymptotic normality; sample is from 2003 to 2008; exogenous variables are individual effects, automatic selection of maximum lags, automatic lag length selection based on SIC: 0, Newly-West automatic bandwidth selection using Bartlett kernel, and balanced observations for each test. 
The results of Pairwise Granger causality test between the two series are reported in Table 4. Within the panel data frameworks, because Granger tests incorporate significantly more observations with shorter time, they produce more efficient results than Granger tests with the conventional time series. When only one lag is included, the study detects no causality in either direction for the individual income groups or all the income groups combined. The robustness of this result across four separate regressions can be interpreted as an indication that a one-year time period is too short to allow causality to take hold. In addition, the study fails to suggest causality in either direction for the upper-middle or lower-middle income groups. However, the study suggests that Granger causality runs one-way from ICT expenditure series to rate of growth of GDP per capita series and not the other way around for the high income group and the all income groups combined with lags longer than one year. Also, the study reveals bi-directional causality when four lags included for only the all income groups combined.

Table 4

Pairwise Panel Granger Causality Test: 2003-2008

\begin{tabular}{|c|c|c|c|c|c|c|}
\hline \multicolumn{7}{|c|}{ High Income Group, Cross Sections: 31} \\
\hline \multicolumn{4}{|c|}{$\begin{array}{l}\mathrm{H}_{0}: \text { ICT Exp. (\% of GDP) DOES NOT Granger } \\
\text { cause rate of growth of per capita GDP }\end{array}$} & \multicolumn{3}{|c|}{$\begin{array}{l}\mathrm{H}_{0} \text { : Rate of growth of per capita GDP } \\
\text { DOES NOT Granger cause ICT Exp. (\% of GDP) }\end{array}$} \\
\hline & Obs. & $F$-Stat. & Prob. & & $F$-Stat. & Prob. \\
\hline Lag: 1 & 155 & 0.223 & 0.637 & Lag: 1 & 0.255 & 0.614 \\
\hline Lag: 2 & 124 & 11.370 & 0.000 & Lag: 2 & 0.298 & 0.743 \\
\hline Lag: 3 & 93 & 6.563 & 0.001 & Lag: 3 & 1.563 & 0.204 \\
\hline Lag: 4 & 62 & 3.021 & 0.026 & Lag: 4 & 0.745 & 0.566 \\
\hline \multicolumn{7}{|c|}{ Upper-Middle Income Group, Cross Sections: 18} \\
\hline \multicolumn{4}{|c|}{$\begin{array}{l}\mathrm{H}_{0}: \text { ICT Exp. (\% of GDP) DOES NOT Granger } \\
\text { cause rate of growth of per capita GDP }\end{array}$} & \multicolumn{3}{|c|}{$\begin{array}{l}\mathrm{H}_{0}: \text { Rate of growth of per capita GDP } \\
\text { DOES NOT Granger cause ICT Exp. (\% of GDP) }\end{array}$} \\
\hline & Obs. & $F$-Stat. & Prob. & & $F$-Stat. & Prob. \\
\hline Lag: 1 & 90 & 0.900 & 0.345 & Lag: 1 & 0.017 & 0.898 \\
\hline Lag: 2 & 72 & 0.130 & 0.879 & Lag: 2 & 1.146 & 0.324 \\
\hline Lag: 3 & 54 & 0.059 & 0.981 & Lag: 3 & 0.727 & 0.541 \\
\hline Lag: 4 & 36 & 1.460 & 0.242 & Lag: 4 & 1.766 & 0.165 \\
\hline \multicolumn{7}{|c|}{ Lower-Middle Income Group, Cross Sections: 19} \\
\hline \multicolumn{4}{|c|}{$\begin{array}{l}\mathrm{H}_{0}: \text { ICT Exp. (\% of GDP) DOES NOT Granger } \\
\text { cause rate of growth of per capita GDP }\end{array}$} & \multicolumn{3}{|c|}{$\begin{array}{l}\mathrm{H}_{0}: \text { Rate of growth of per capita GDP } \\
\text { DOES NOT Granger cause ICT Exp. (\% of GDP) }\end{array}$} \\
\hline & Obs. & $F$-Stat. & Prob. & & $F$-Stat. & Prob. \\
\hline Lag: 1 & 95 & 0.384 & 0.537 & Lag: 1 & 0.376 & 0.566 \\
\hline Lag: 2 & 76 & 0.239 & 0.788 & Lag: 2 & 1.489 & 0.233 \\
\hline Lag: 3 & 57 & 0.891 & 0.453 & Lag: 3 & 1.314 & 0.280 \\
\hline Lag: 4 & 38 & 3.345 & 0.023 & Lag: 4 & 1.479 & 0.234 \\
\hline \multicolumn{7}{|c|}{ All Income Group, Cross Sections: 70} \\
\hline \multicolumn{4}{|c|}{$\begin{array}{l}\mathrm{H}_{0}: \text { ICT Exp. (\% of GDP) DOES NOT Granger } \\
\text { cause rate of growth of per capita GDP }\end{array}$} & \multicolumn{3}{|c|}{$\begin{array}{l}\mathrm{H}_{0} \text { : Rate of growth of per capita GDP } \\
\text { DOES NOT Granger cause ICT Exp. (\% of GDP) }\end{array}$} \\
\hline & Obs. & $F$-Stat. & Prob. & & $F$-Stat. & Prob. \\
\hline Lag: 1 & 350 & 0.974 & 0.325 & Lag: 1 & 0.082 & 0.775 \\
\hline Lag: 2 & 280 & 3.167 & 0.044 & Lag: 2 & 1.609 & 0.202 \\
\hline Lag: 3 & 210 & 3.125 & 0.027 & Lag: 3 & 1.498 & 0.216 \\
\hline Lag: 4 & 140 & 4.810 & 0.001 & Lag: 4 & 2.465 & 0.048 \\
\hline
\end{tabular}




\section{Conclusions}

The primary motivation of this study was to enhance the understanding of the contribution of investment in ICT capital to economic growth. It re-examines the findings of previous studies, such as Schreyer (2000), Colecchia and Schreyer (2002), Baliamoune-Lutz (2003), Beil et al. (2005), Papaioannou and Dimelis (2007), and Ngwenyama and Morawczynski (2009), by adapting a different model and using a unique set of data set for defined groups of developed and developing countries. The Pairwise Granger causality test is implemented to verify the existence of Granger causality between ICT expenditure (\% of GDP) and the rate of growth of GDP per capita series for a total of 70 countries over the period from 2003 to 2008 . This procedure increases the number of observations which is shown to have higher testing power than the tests based on individual time series alone.

The study suggests that Granger causality runs one-way from ICT expenditure series to the rate of growth of GDP per capita series (and not in the other direction) for the high income group and the all income groups combined with lags longer than one year. Also, the study reveals bi-directional causality, when four lags included for only the all income groups combined. On the contrary, with the inclusion of one lag, the study detects no causality in either direction for the individual income groups or all the income groups combined. The robustness of this result across four separate income groups can be interpreted as an indication that a one-year time period is not long enough to allow causality to take hold. In addition, the study does not suggest causality in either direction for the upper-middle or lower-middle income groups. Therefore, separation of the countries into defined income groups appears to help shed light into identifying causality between the rate of growth of GDP per capita and ICT expenditure series.

This paper, on one hand, suggests causality from investments in ICT to the growth of GDP for developed or high income countries which is consistent with the findings of previous studies, such as Schreyer (2000) for the G7 (the group of seven major advanced economies) countries and OECD (2003). One reason for the contribution of ICT is that these economies benefit from the full return of ICT stock of capital because of the existing human capital, infrastructure, and other enabling factors. On the other hand, this study does not find causality for developing countries, the middle-income groups combined. This result is, however, similar with that of Baliamoune-Lutz (2002) which suggests that GDP does not have an effect on certain ICT indicators; and ICT diffusion, as measured by dissemination of Internet use, is not associated with higher income. In other words, the marginal rate of return on investment in ICT capital for developing countries has not been as high as that for developed countries. The study, by Papaioannou and Dimelis (2007) which examines the impact of ICT for 42 developed and developing countries over the period from 1993 to 2001, confirms that whereas evidence is provided that developing countries have started to benefit from ICT, its impact is lower compared to that of developed countries.

In sum, it seems reasonable to conclude that causality between expenditure in ICT and the rate of growth of GDP per capita series depends on two factors: (1) the stage of development, as measured by the income level, of the group of countries; and (2) the number of lags included in the regression equation. In particular, the longer the lags are, the higher the likelihood of investment in ICT Granger causes the rate of growth of GDP per capita.

A major policy implication which emerges from this study is that to achieve a potentially higher return to ICT, developing nations need to consider a balanced investment on both ICT capital and the enabling factors, 
including ICT infrastructure. Clearly, such a balanced investment depends, among many socioeconomic factors, on the stage of development of each developing country. This confirms the policy recommendations suggested by Ngwenyama and Morawczynski (2009) for five emerging economies in Latin America and Ayanso, Cho, and Lertwachara (2010). Developing nations would also need to promote openness, and enhance trade and industrial policies in order to benefit from the full potential of investment in ICT, and foster economic growth.

Finally, a drawback with this study is that it does not produce country-specific causality estimates. Specifically, the results of this study should not be interpreted as a suggestion of "one-size-fits-all". However, with the availability of data series, this modeling can be tested for individuals as well as groups of neighboring countries with similar economic conditions.

\section{References}

Ahmad, N., Schreyer, P., \& Wölfl, A. (2004). ICT investment in OECD countries and its economic impacts-The economic impact of ICT: Measurement, evidence and implications. Paris: OECD.

Armstrong, P., Harchaoui, T. M., Jackson, C., \& Tarkhani, F. (2002). A comparison of Canada-US economic growth in the information age, 1981-2000: The importance of investment in information and communication technologies (Economic Analysis Research Paper Series, No. 001, Statistics Canada, Ottawa).

Atrostic, B. K., \& Nguyen, S. (2002). Computer networks and US manufacturing plant productivity: New evidence from the CNUS data (CES Working Paper 02-01, Center for Economic Studies, Washington, DC).

Ayanso, A., Cho, D. I., \& Lertwachara, K. (2010). The digital divide: Global and regional ICT leaders and followers. Information Technology for Development, 16(4), 304-319.

Baliamoune-Lutz, M. (2003). An analysis of the determinants and effects of ICT diffusion in developing countries. Information Technology for Development, 10, 151-169.

Becchetti, L., \& Adriani, F. (2005). Does the digital divide matter? The role of information and communication technology in cross-country level and growth estimates. Economics of Innovation and New Technology, 14(6), 435-453.

Beil, R. O., Ford, G. S., \& Jackson, J. D. (2005). On the relationship between telecommunications investment and economic growth in the United States. International Economic Journal, 19(1), 3-9.

Cette, G., Mairesse, J., \& Kocoglu, Y. (2002). Diffusion of ICTs and growth of the French economy over the long term, 1980-2000. International Productivity Monitor, 4, 27-38.

Colecchia, A., \& Schreyer, P. (2002). ICT investment and economic growth in the 1990s: Is the United States a unique case? A comparative study of nine OECD countries. Review of Economics Dynamics, 5(2), 408-442.

Daveri, F. (2002). The new economy in Europe, 1992-2001. Oxford Review of Economic Policy, 18(3), 345-362.

Dewan, S., \& Kraemer, K. (2000). Information technology and productivity: Evidence from country-level data. Management Science, 46(4), 548-562.

Dickey, D. A., \& Fuller, W. A. (1979). Distribution of the estimators for autoregressive time series with a unit root. Journal of the American Statistical Association, 74, 427-431.

Engle, R. F., \& Granger, C. W. J. (1987). Cointegration and error correction: Representation, estimation and testing. Econometrica, $55,251-276$.

Ferran, C., \& Salim, R. (2006). Electronic business in developing countries: The digitalization of bad practices? In S. Kamel (Ed.), Electronic business in developing countries: Opportunities and challenges (pp. 1-33). Hershey: IDEA Group Publishing.

Ghali, K. H., \& Al-Mutawa, A. (1999). The intertemporal causal dynamics between fixed capital formation and economic growth in the group-of-seven countries. International Economic Journal, 13(2), 31-37.

Gordon, R., \& Rhine-Westphalia Institute of Economic Research. (2002). New economy-An assessment from a German viewpoint. Essen: Rhine-Westphalia Institute for Economic Research.

Granger, C. W. J. (1969). Investigating causal relations by econometric models: Cross spectral methods. Econometrica, 37, 424-438.

Granger, C. W. J. (1988). Some recent developments in a concept of causality. Journal of Econometrics, 39, $199-211$. 
Gretton, P., Gali, J., \& Parham, D. (2002). Uptake and impacts of ICT in the Australian economy: Evidence from aggregate, sectoral and firm levels (OECD Workshop on ICT and Business Performance, Productivity Commission, Canberra).

Hamilton, R. (1994). Time series analysis. Princeton: Princeton University Press.

Im, K. S., Pesaran, M. H., \& Shin, Y. (2003). Testing for unit roots in heterogenous panels. Journal of Econometrics, 115, 53-74.

Jalava, J., \& Pohjola, M. (2002). ICT as a source of output and productivity growth in Finland (Helsinki Center for Economic Research, Discussion Paper No. 52).

Jorgenson, D. W., Ho, M. S., \& Stiroh, K. J. (2002). Projecting productivity growth: Lessons from the US growth resurgence. Economic Review, 87(3), 1-13.

Kegels, C., Van Overbeke, M., \& Van Zandweghe, W. (2002). ICT contribution to economic performance in Belgium: Preliminary evidence (Working Paper 8-02, Federal Planning Bureau, Brussels).

Khan, H., \& Santos, M. (2002). Contribution of ICT use to output and labour: Productivity growth in Canada (Working Paper 2002-7, Bank of Canada, Ottawa, March).

Kim, S. J. (2002). The digital economy and the role of government: Information technology and economic performance in Korea (Program on Information Resources Policy, Harvard University).

Kottemann, J. E., \& Boyer-Wright, K. M. (2009). Human resource development, domains of information technology use, and levels of economic prosperity. Information Technology for Development, 15(1), 32-42.

Levin, A., Lin, C. F., \& Chu C. (2002). Unit root tests in panel data: Asymptotic and finite-sample properties. Journal of Econometrics, 108, 1-24.

Miyagawa, T., Y. I., \& Harada, N. (2002). Does the IT revolution contribute to Japanese economic growth? (JCER Discussion Paper No. 75, Japan Center for Economic Research, Tokyo).

Motohashi, K. (2001). Economic analysis of information network use: Organizational and productivity impacts on Japanese firms (Research and Statistics Department, METI, mimeo).

Ngwenyama, O., \& Morawczynski, O. (2009). Factors affecting ICT expansion in emerging economies: An analysis of ICT infrastructure expansion in five Latin American countries. Information Technology for Development, 15(4), 237-258.

Oliner, S. D., \& Sichel, D. E. (2000). The resurgence of growth in the late 1990s: Is information technology the story? The Journal of Economic Perspectives, 14(4), 3-22.

Organisation for Economic Co-operation and Development. (2003). ICT and economic growth: Evidence from OECD countries, industries and firms. Retrieved from https://books.google.ca/books?id=zS8v2aFE8LYC\&dq=ISBN+92-64-10128-4\&source=gbs_navlinks_s

Oulton, N. (2001). ICT and productivity growth in the United Kingdom (Working Paper No. 140, Bank of England, London).

Panagariya, A. (2000). E-commerce, WTO and developing countries. The World Economy, 23(8), 959-978.

Papaioannou, S. K., \& Dimelis, S. P. (2007). Information technology as a factor of economic development: Evidence from developed and developing countries. Economics of Innovation and New Technology, 16(3), 179-194.

Parham, D., Roberts, P., \& Sun, H. (2001). Information technology and Australia's productivity surge (Staff Research Paper, Productivity Commission, AusInfo, Canberra).

Pesaran, M. H., \& Shin, Y. (1995). An autoregressive distributed lag modeling approach to cointegrated analysis (Discussion Paper 95-14, Department of Applied Economics, University of Cambridge).

Pesaran, M. H., Shin, Y., \& Smith, R. J. (2000). Structural analysis of vector error correction models with exogenous I(1) variable. Journal of Econometrics, 97, 293-343.

Phillips, P. C. B., \& Perron, P. (1988). Testing for a unit root in time series regression. Biometrika, 75, 335-346.

Podrecca, E., \& Carmeci, G. (2001). Fixed investment and economic growth: New results on causality. Applied Economics, 33(2), 177-182.

Schreyer, P. (2000). The contribution of information and communication technology to output growth: A study of the G7 countries. Retrieved from http://www.oecd-ilibrary.org/science-and-technology/ the-contribution-of-information-and-communication-technology-to-output-growth_151634666253

Simon, J., \& Wardrop, S. (2002). Australian use of information technology and its contribution to growth (Research Discussion Paper RDP2002-02, Reserve Bank of Australia, Sydney).

Solow, R. (1956). A contribution to the theory of economic growth. Quarterly Journal of Economics, 70, 65-94.

Solow, R. (1957). Technical change and the aggregate production function. Review of Economics and Statistics, 39(3), 65-94.

Toda, H. Y., \& Yamamoto, T. (1995). Statistical inference in vector autoregressions with possibly integrated processes. Journal of Econometrics, 66, 225-250. 
Van Ark, B., Melka, J., Mulder, N., Timmer, M., \& Ypma, G. (2002). ICT investments and growth accounts for the European Union, 1980-2000 (Research Memorandum GD-56, Groningen Growth and Development Center, Groningen).

Van Der Wiel, H. (2001). Does ICT boost Dutch productivity growth? (CPB Document No. 016, CPB Netherlands Bureau of Economic Policy Analysis).

Wolde-Rufael, Y. (2007). Another look at the relationship between telecommunications investment and economic activity in the United States. International Economic Journal, 21(2), 199-205.

World Bank. (2015). World development indicators. Retrieved from

http://data.worldbank.org/data-catalog/world-development-indicators 
Appendix 1: Income Groups

\begin{tabular}{|c|c|c|}
\hline High income group & Upper-middle income group & Lower-middle income group \\
\hline $\begin{array}{l}\text { Australia } \\
\text { Austria } \\
\text { Belgium } \\
\text { Canada } \\
\text { Czech Republic } \\
\text { Denmark } \\
\text { Finland } \\
\text { France } \\
\text { Germany } \\
\text { Greece } \\
\text { Hong Kong, China } \\
\text { Hungary } \\
\text { Ireland } \\
\text { Israel } \\
\text { Italy } \\
\text { Japan } \\
\text { Korea, Rep. } \\
\text { Netherlands } \\
\text { New Zealand } \\
\text { Norway } \\
\text { Poland } \\
\text { Portugal } \\
\text { Saudi Arabia } \\
\text { Singapore } \\
\text { Slovak Republic } \\
\text { Slovenia } \\
\text { Spain } \\
\text { Sweden } \\
\text { Switzerland } \\
\text { United Kingdom } \\
\text { United States }\end{array}$ & $\begin{array}{l}\text { Algeria } \\
\text { Argentina } \\
\text { Brazil } \\
\text { Bulgaria } \\
\text { Chile } \\
\text { Colombia } \\
\text { Costa Rica } \\
\text { Jamaica } \\
\text { Malaysia } \\
\text { Mexico } \\
\text { Panama } \\
\text { Peru } \\
\text { Romania } \\
\text { Russian Federation } \\
\text { South Africa } \\
\text { Turkey } \\
\text { Uruguay } \\
\text { Venezuela, RB }\end{array}$ & $\begin{array}{l}\text { Bolivia } \\
\text { Cameroon } \\
\text { China } \\
\text { Ecuador } \\
\text { Egypt, Arab Rep. } \\
\text { Honduras } \\
\text { India } \\
\text { Indonesia } \\
\text { Jordan } \\
\text { Morocco } \\
\text { Nigeria } \\
\text { Pakistan } \\
\text { Philippines } \\
\text { Senegal } \\
\text { Sri Lanka } \\
\text { Thailand } \\
\text { Tunisia } \\
\text { Ukraine } \\
\text { Vietnam }\end{array}$ \\
\hline
\end{tabular}

Appendix 2: Definitions

\begin{tabular}{|l|l|}
\hline Items & Definitions \\
\hline Information and Communication Technologies (ICT) & $\begin{array}{l}\text { It consists of the hardware, software, networks, and media for } \\
\text { the collection, storage, processing, transmission and } \\
\text { presentation of information (voice, data, text, and images), as } \\
\text { well as related services. ICT can be split into ICI and IT. }\end{array}$ \\
\hline Information and Communication Infrastructure (ICI): & $\begin{array}{l}\text { It refers to physical telecommunications systems and networks } \\
\text { (cellar, broadcast, cable, satellite, and postal) and the services } \\
\text { that utilize them (Internet, voice, mail, radio, and television). }\end{array}$ \\
\hline Information Technology (IT) & $\begin{array}{l}\text { It refers to the hardware and software of information collection, } \\
\text { storage, processing, and presentation. }\end{array}$ \\
\hline
\end{tabular}

